University of Chicago Law School

Chicago Unbound

Public Law and Legal Theory Working Papers

Working Papers

2008

\title{
Boumediene and the Uncertain March of Judicial Cosmopolitanism
}

Eric A. Posner

Follow this and additional works at: https://chicagounbound.uchicago.edu/public_law_and_legal_theory

Part of the Law Commons

Chicago Unbound includes both works in progress and final versions of articles. Please be aware that a more recent version of this article may be available on Chicago Unbound, SSRN or elsewhere.

\section{Recommended Citation}

Eric Posner, "Boumediene and the Uncertain March of Judicial Cosmopolitanism" (University of Chicago Public Law \& Legal Theory Working Paper No. 228, 2008).

This Working Paper is brought to you for free and open access by the Working Papers at Chicago Unbound. It has been accepted for inclusion in Public Law and Legal Theory Working Papers by an authorized administrator of Chicago Unbound. For more information, please contact unbound@law.uchicago.edu. 


\title{
CHICAGO
}

Public LaW and Legal Theory Working Paper No. 228



\section{BOUMEDIENE AND THE UNCERTAIN MARCH OF JUDICIAL COSMOPOLITANISM}

\author{
Eric A. Posner \\ THE LAW SCHOOL \\ THE UNIVERSITY OF CHICAGO
}

August 2008

This paper can be downloaded without charge at the Public Law and Legal Theory Working Paper Series: http://www.law.uchicago.edu/academics/publiclaw/index.html and The Social Science Research Network Electronic Paper Collection. 


\title{
Boumediene and the Uncertain March of Judicial Cosmopolitanism
}

\author{
Eric A. Posner ${ }^{1}$
}

August 1, 2008

\begin{abstract}
In Boumediene v. Bush, the Supreme Court held that noncitizens detained at Guantanamo Bay have the constitutional privilege of habeas corpus. The case can be given multiple interpretations, including a narrow reading under which it follows straightforwardly from Eisentrager. But Justice Kennedy's majority opinion omits consideration of a factor that plays a role in Eisentrager, namely, the limited constitutional status of the noncitizen. For this reason, the most distinctive element of Justice Kennedy's reasoning is its cosmopolitanism, not its libertarianism. The cosmopolitan elements of Boumediene recall the debate about the use of foreign law to interpret provisions of the U.S. Constitution, of which Justice Kennedy is a major proponent, and it is argued that critics of judicial cosmopolitanism should reject Boumediene as well.
\end{abstract}

In Boumediene v. Bush, the Supreme Court held that noncitizens detained at Guantanamo Bay have the constitutional privilege of habeas corpus and that the review procedures established by the Detainee Treatment Act do not provide an adequate substitute for habeas corpus. The majority opinion written by Justice Kennedy rests the holding on what he calls a theory of separation of powers, but on inspection it becomes clear that the real basis of the opinion lies elsewhere. The holding turns on an implicit theory about the rights of noncitizens, a theory that is prior to the conception of separation of powers, as I shall explain, and is essentially about who belongs to the political community or demos. Justice Kennedy's theory is, I will argue, a cosmopolitan theory.

Shortly after 9/11, Congress passed the Authorization for Use of Military Force, which authorized the President "to use all necessary and appropriate force against those nations, organizations, or persons he determines planned, authorized, committed, or aided the terrorist attacks that occurred on September 11, 2001, or harbored such organizations or persons, in order to prevent any future acts of international terrorism against the United States by such nations, organizations or persons." ${ }^{2}$ The Bush administration claimed that the AUMF authorized the military to detain and hold "enemy combatants," a position that was accepted by the Supreme Court in Hamdi v. Rumsfeld. ${ }^{3}$ But the Court also held that the detainees were entitled to a procedure that allows them to contest their status as enemy combatants. The Bush administration attempted to comply by establishing Combatant Status Review Tribunals. CSRTs determined that the petitioners in Boumediene were enemy combatants, whereupon they filed writs of habeas corpus.

\footnotetext{
${ }^{1}$ Many thanks to Scott Anderson, Curt Bradley, Mary Anne Case, Adam Cox, Mark Heyrman, Jens Ludwig, Madhavi Sunder, Adrian Vermeule, and participants at a workshop at the University of Chicago, for helpful comments, and Ben Burry for research assistance.

${ }^{2}$ Authorization for Use of Military Force, Pub. L. No. 107-40, 115 Stat. 224 (2001).

${ }^{3}$ Hamdi v. Rumsfeld, 542 U.S. 507, 509 (2004).
} 
Meanwhile, Congress passed the Detainee Treatment Act, which stripped federal district courts of jurisdiction over writs of habeas corpus filed by noncitizens held at Guantanamo Bay and gave the D.C. Circuit the exclusive authority to conduct a limited review of the determinations of CSRTs. ${ }^{4}$ After the Supreme Court held, in Hamdan v. Rumsfeld, ${ }^{5}$ that these provisions did not apply to petitions filed before the DTA was enacted, Congress passed the Military Commissions Act, which provided that the habeas-stripping provision of the DTA would apply to pending petitions as well. ${ }^{6}$

The government's argument in Boumediene was that under the eighteenth century common law understanding of the writ of habeas corpus, the writ was not available to detainees held outside sovereign territory, that this understanding of habeas corpus was incorporated into the U.S. Constitution's suspension clause, and that Guantanamo Bay is not American sovereign territory. ${ }^{7}$ Finding no historical evidence that the writ of habeas corpus was available to enemy aliens held abroad, and also no evidence that the writ was not available to enemy aliens held abroad, Justice Kennedy declined to rest his holding on historical understandings. ${ }^{8}$ Instead, he applied what he called principles of separation of powers.

I will argue that the significance of Justice Kennedy's opinion has less to do with separation of powers theory than with a commitment to protecting the interests of noncitizens overseas. I argue that this commitment reflects an emerging type of jurisprudence-which I call "judicial cosmopolitanism." Judicial cosmopolitanism is the view that judges have a constitutional obligation to protect the interests of noncitizens. ${ }^{9}$ After explaining its role in the Boumediene opinion and its novelty in Supreme Court jurisprudence, I briefly criticize it.

\section{Johnson v. Eisentrager}

In Johnson v. Eisentrager, the Supreme Court held that nonresident alien combatants captured in a theater of war and convicted of war crimes by a military commission did not have the right to petition for habeas corpus in American courts. ${ }^{10}$ American forces had captured German soldiers who were giving assistance to the Japanese after the surrender of Germany but before the surrender of Japan.

\footnotetext{
${ }^{4} 42$ U.S.C.A. § 2000dd (2007).

${ }^{5} 548$ U.S. 557 (2006).

${ }^{6}$ Pub. L. No. 109-366, 120 Stat. 2600 (2006) (to be codified in scattered sections of 10, 18, 28, and 42 U.S.C.).

${ }^{7}$ Boumediene v. Bush, No. 06-1195, slip op. at 22 (U.S. 2008).

${ }^{8}$ Id. at 22.

${ }^{9}$ The term has been used by others in a broader sense-to refer to the use of foreign sources for the purpose of constitutional interpretation. See, e.g., Ken I. Kersch, The New Legal Transnationalism, The Globalized Judiciary, and the Rule of Law, 4 Wash. U. Global Stud. L. Rev. 345 (2005), who appears to be the first to use the term in this way. I will discuss the relationship between these two types of judicial cosmopolitanism below. Kennedy, of course, is known for his cosmopolitan tendencies, e.g., in United States v. Verdugo-Urquidez, 494 U.S. 259,275 (1990) (Kennedy, J., concurring); Roper v. Simmons, 543 U.S. 551 (2005); Lawrence v. Texas, 539 U.S. 558, 568-74 (2003).

10 Johnson v. Eisentrager, 339 U.S. 763 (1950).
} 
The opinion written by Justice Jackson mentions a number of reasons for its holding, but in summary form, necessitating speculation about what he meant. At least the following factors, in some combination, played a role, though it is not clear whether all or some of them were necessary to the result, or the result occurred as a consequence of their cumulative impact.

First, Justice Jackson emphasized the petitioners' alien status: they did not have habeas rights because they were aliens outside American territory, or perhaps enemy aliens (whether or not outside American territory). By contrast, (non-enemy?) resident aliens obtain rights as a result of their "preliminary declaration of intention to become a citizen," ${ }^{11}$ implying that rights go to those who appear (increasingly) loyal to the United States or who have located on American territory where the power of American courts is at its height.

Underlying this inquiry is an idea about political community. People in the American political community are entitled to certain rights that are denied to those outside it. Aliens overseas, and certainly enemy aliens overseas, do not belong to the American political community and therefore are entitled to no, or few, rights. American citizens do belong to that community, even those who have joined the enemy. Aliens on American territory occupy an ambiguous middle ground, because many of them do plan to become Americans, or have otherwise sunk roots into, and to some extent participate in, the American political community, as quasi-citizens.

Second, in a famous passage, Justice Jackson speculated about the practical and logistical difficulties that would follow if enemy aliens were given habeas rights:

A basic consideration in habeas corpus practice is that the prisoner will be produced before the court. ... To grant the writ to these prisoners might mean that our army must transport them across the seas for hearing. This would require allocation of shipping space, guarding personnel, billeting and rations. It might also require transportation for whatever witnesses the prisoners desired to call as well as transportation for those necessary to defend legality of the sentence. The writ, since it is held to be a matter of right, would be equally available to enemies during active hostilities as in the present twilight between war and peace. Such trials would hamper the war effort and bring aid and comfort to the enemy. They would diminish the prestige of our commanders, not only with enemies but with wavering neutrals. It would be difficult to devise more effective fettering of a field commander than to allow the very enemies he is ordered to reduce to submission to call him to account in his own civil courts and divert his efforts and attention from the military offensive abroad to the legal defensive at home. Nor is it unlikely that the result of such enemy litigiousness would be a conflict between judicial and military opinion highly comforting to enemies of the United States.

Moreover, we could expect no reciprocity for placing the litigation weapon in unrestrained enemy hands. The right of judicial refuge from military action, which it is proposed to bestow on the enemy, can purchase no equivalent for benefit of our citizen soldiers. Except in England, whose law appears to be in harmony with the views we have expressed, and other English-

${ }^{11}$ Id. at 770 . 
speaking peoples in whose practice nothing has been cited to the contrary, the writ of habeas corpus is generally unknown. ${ }^{12}$

Here we see concerns about the sheer financial cost of habeas hearings when prisoners, custodians, and witnesses are overseas; the military risk of transporting such people; the positive morale effect for the enemy and the negative morale effect for Americans; interference with command; and the absence of any reciprocal benefit that would be conferred upon the United States by the enemy if habeas rights were recognized. Justice Jackson does not express doubts about the capacity of judges to evaluate the military's reasons for detention, but he hints that disagreement between the judiciary and the military is likely to occur, which would be "comforting" to the enemy.

This concern about logistics involves a more familiar and uncomplicated national-interest analysis than the political-community question does. Supposing that a habeas petitioner does belong to the political community, or does so to a sufficient extent-because he is an American, or an alien on American territory-what rights protections are reasonable given the conflicting interest of national security? Depending on the setting, it will be more or less costly, difficult, and dangerous for the military to comply with the requirements of a habeas hearing. Normal procedural protections can be compromised in light of these problems-indeed, the entire military justice system reflects such compromises.

Third, Justice Jackson might have believed that the petitioners did not have habeas rights because the military commissions gave them adequate process. ${ }^{13}$ This interpretation was advanced by Justice Kennedy in Boumediene, who says that one of the reasons that Justice Jackson refused to extend habeas rights to the petitioners in Eisentrager is that the petitioners there benefited from the military commissions, which provided "a rigorous adversarial process to test the legality of their detention," whereas the CSRTs that heard the petitioners' case provided more limited process. ${ }^{14}$ This seems to be a misreading of Eisentrager. In the section of the opinion that explains the holding, Justice Jackson does not say that the military commissions provide adequate process. Justice Kennedy cites a passage where Justice Jackson merely summarizes the factual setting, and the reference to the military commission seems to be intended merely to show how exotic the petitioners' claim is. ${ }^{15}$

\section{Boumediene}

\section{A. A Narrow Reading}

One reading of Boumediene is that it does not advance the law at all, and simply applies the Eisentrager precedent to a novel set of facts. Eisentrager said that aliens held outside American sovereign territory have no habeas rights, and the question in Boumediene was whether Guantanamo Bay should be considered part of America's sovereign territory or not. The government misinterpreted

\footnotetext{
${ }^{12}$ Id. at 778-79.

${ }^{13}$ It is sometimes said that the result turned on the fact that the petitioners did not contest their status as enemy combatants. If that is the case, then Eisentrager was a trivial decision, as no one would make that mistake again.

${ }^{14}$ Boumediene, No. 06-1195 U.S. slip op. at 37.

${ }^{15}$ Boumediene, No. 06-1195 U.S. slip op. at 36 (quoting Eisentrager 399 U.S. at 777).
} 
the Eisentrager test as turning on de jure sovereignty; in fact, the right interpretation of Eisentrager is "effective control." Rasul had already addressed this issue within the statutory habeas framework and held that Guantanamo Bay is, for habeas purposes, part of America's territory. ${ }^{16}$ Boumediene comes to the same conclusion as a matter of constitutional law.

On this view, the jurisprudential significance of Boumediene is nil or close to it, though it might be practically important. All that it did was change the form of the law: it changed the Eisentrager rule into a standard by converting the reasons behind the Eisentrager rule into governing law. The government had manipulated the Eisentrager rule, according to Justice Kennedy, by holding the detainees in territory over which the United States had de facto but not de jure control: we shouldn't care about the rule but the reasoning behind it, and so such manipulation can't be tolerated. This is, of course, a common response among judges when they see rules being manipulated, and although the response is understandable, it inevitably undervalues the reasons for rules-their predictability. So the government loses the power to manipulate but also to engage in reasonable planning. Whether Justice Kennedy was right to think that the balance between decision and error costs favored a standard in this case rather than a rule will become clear only with time.

But what was the standard that was embodied in the reasoning of Eisentrager? Justice Jackson gave reasons for his rule; he did not state a standard. He might have offered these reasons in the alternative or he might have thought they were mutually reinforcing. In drawing a standard from Justice Jackson's reasoning, Justice Kennedy had the opportunity to change the emphasis among these reasons, and thus change the substance of the law. This, I will argue, he did.

\section{B. A Broader Reading}

Justice Kennedy argues that the writ of habeas corpus serves the principles of separation of powers by creating a judicial check on the political branches. The theory is stated about halfway through the discussion:

The necessary implication of the [government's] argument is that by surrendering formal sovereignty over any unincorporated territory to a third party, while at the same time entering into a lease that grants total control over the territory back to the United States, it would be possible for the political branches to govern without legal constraint.

Our basic charter cannot be contracted away like this. The Constitution grants Congress and the President the power to acquire, dispose of, and govern territory, not the power to decide when and where its terms apply. Even when the United States acts outside its borders, its powers are not "absolute and unlimited" but are subject "to such restrictions as are expressed in the Constitution." Murphy v. Ramsey, 114 U. S. 15, 44 (1885). Abstaining from questions involving formal sovereignty and territorial governance is one thing. To hold the political branches have the power to switch the Constitution on or off at will is quite another. The former position reflects this Court's recognition that certain matters requiring political

\footnotetext{
${ }^{16}$ Rasul v. Bush, 542 U.S. 466 (2004).
} 
judgments are best left to the political branches. The latter would permit a striking anomaly in our tripartite system of government, leading to a regime in which Congress and the President, not this Court, say "what the law is." Marbury v. Madison, 1 Cranch 137, 177 (1803). ${ }^{17}$

As an aside, note that it is questionable that the writ of habeas corpus can be understood as a check on both the political branches given that Congress has the power to suspend the writ. True, Congress did not (formally) suspend the writ after $9 / 11$, but it probably could have, ${ }^{18}$ in which case the petitioners would have no claim, and the reference to Marbury v. Madison is exposed as hollow. The writ is a check on the executive acting alone, without the concurrence of Congress. Yet the court ends up striking down a statute that Congress had enacted. Perhaps the best that can be said for this argument is that the requirement that Congress "formally" suspend the writ serves as a check on Congress. A formal suspension might be more politically costly than a de facto suspension, even though a de facto suspension will often be clear enough, as was the case here. But normally the Supreme Court does not require Congress to utter magic words in order to discharge its constitutional responsibilities. ${ }^{19}$

But our focus is Justice Kennedy's use of Eisentrager. Justice Kennedy places all weight on the logistical concern in Eisentrager, and very little, perhaps none, on the political-community concern. Justice Kennedy summarizes what he calls the "functional" test of Eisentrager as follows:

(1) the citizenship and status of the detainee and the adequacy of the process through which that status determination was made; (2) the nature of the sites where apprehension and then detention took place; and (3) the practical obstacles inherent in resolving the prisoner's entitlement to the writ. $^{20}$

Notably, Justice Kennedy's discussion of the first factor omits any reference to the petitioners' status as aliens, or enemy aliens, and instead focuses entirely on the adequacy of process question, which, as I argued earlier, he mistakenly reads into Eisentrager. Otherwise, Justice Kennedy addresses the logistical question. Because Guantanamo Bay is fully under control of the United States military, diplomatic frictions will not arise if courts exercise habeas jurisdiction, nor will there be any serious military risks. ${ }^{21}$ By contrast, in Eisentrager, the occupation zone was larger and covered more people; more U.S. military resources were involved; the U.S. shared control of the prison with other countries; and there were potential threats from the defeated.

The focus on logistics may not have been adventitious. It is hard to imagine a weaker case for the logistics argument than Guantanamo Bay, at least compared to other foreign territories. Located only about 500 miles from Florida, it would not seem particularly difficult to transport prisoners and

\footnotetext{
${ }^{17}$ Boumediene, No. 06-1195 U.S. slip op. at 35-36.

${ }^{18}$ Some commentators may think that Congress cannot suspend the writ unless there is an emergency of a sufficient magnitude, and that courts would review suspension of the writ rather than defer. If so, then Justice Kennedy's view is correct.

${ }^{19}$ For example, there is no rule that Congress must echo the text and announce a declaration of war in order to authorize hostilities.

${ }^{20}$ Boumediene, No. 06-1195 U.S. slip op. at 36-37.

${ }^{21}$ Id. at 38-39.
} 
soldiers to a federal district court. Nor does the type of risk involved seem measurably greater than the risk of transferring a dangerous criminal from a prison to a court. True, many of the witnesses are in Afghanistan, Iraq, and elsewhere throughout the world. But that is possible in ordinary criminal cases, and not a reason to foreclose habeas. Justice Kennedy notes that the habeas court will give deference to the government when deference is justified, and this forecloses, at least until experience proves otherwise, the argument that habeas hearings are logistically impossible or unreasonable. ${ }^{22}$

Unmentioned is the status of the noncitizen. An oblique reference can be found in this passage only:

It is true that before today the Court has never held that noncitizens detained by our Government in territory over which another country maintains de jure sovereignty have any rights under our Constitution. But the cases before us lack any precise historical parallel. They involve individuals detained by executive order for the duration of a conflict that, if measured from September 11, 2001, to the present, is already among the longest wars in American history. $^{23}$

Why should it matter that this conflict is among the longest wars in American history? The only possible answer is that the interests of the detainee must be taken into account, and it is worse to be detained for a very long conflict than it is to be detained for a short conflict.

So here is a theory. Justice Jackson refused to extend habeas rights to overseas enemy aliens for two reasons - the interests of these overseas aliens do not "count" like those of Americans, and the logistical demands on the military would be unreasonable. Justice Kennedy barely sees, and hardly acknowledges, the first point, and is not willing to countenance it. That leaves him with the logistical issue, which seems to melt away for Guantanamo Bay, with its convenient location and status as a de facto American territory, and the consideration that courts can always make concessions to logistics on a case by case basis, deferring to the military when they must but not otherwise.

Logistics just won't get one very far; the crucial assumption in Eisentrager is that overseas noncitizens are not entitled to judicial process, logistics or no logistics. Why doesn't Justice Kennedy confront what seemed like a natural assumption to Justice Jackson-that nonresident aliens just don't have the rights that Americans have, and thus don't deserve judicial protection of any sort? The answer is that Justice Kennedy is a cosmopolitan.

III. The Application of the Constitution Overseas

The main question posed by Boudemiene is this: should nonresident aliens be treated as Americans, or at least be given some of the rights of Americans?

\footnotetext{
${ }^{22}$ Id. at 41 . A similar focus on logistics appeared in Justice Kennedy's concurring opinion in Verdugo-Urquidez, which involved the extraterritorial application of the fourth amendment.. See Verdugo-Urquidez, 494 U.S. at 278.

${ }^{23}$ Boumediene, slip op. at. 41.
} 
The relevant literature is not the separation-of-powers literature, but the literature on the extraterritorial application of the Constitution. The literature arises from a series of cases, some but not all of them discussed in Boumediene, ${ }^{24}$ that have addressed whether the Constitution-or certain provisions of it-constrains the U.S. government when it operates abroad. The answer, for the most part, is "no," except when government action affects Americans, or resident aliens who have partially joined the political community, or quasi-Americans who live in territories that the United States has acquired. ${ }^{25}$ But tantalizing hints in some of the cases suggest that the "no" is not a hard "no," 26 and Boumediene has, for the first time, suggested that in fact the "no" is a "yes."

Therein lies the significance of Boumediene. It is the first Supreme Court case that appears to recognize that noncitizens on foreign soil have constitutional rights secured by judicial oversight. ${ }^{27}$ It is possible that Boumediene will have little impact in the future. Courts that hear habeas petitions coming from abroad might give deference to the military, ${ }^{28}$ or not recognize any substantive constitutional rights beyond the habeas right itself. It is also possible that in a future case, the Court will confine Boumediene to the facts, treating Guantanamo Bay as unique because U.S. control is complete and Cuban sovereignty so clearly fictional. But in a more general jurisprudential sense, the opinion signifies the increasing influence of cosmopolitanism on the Court.

A. What Is Judicial Cosmopolitanism?

There has been much talk of judicial cosmopolitanism in recent years, stimulated by handful of Supreme Court cases that cite foreign and international law in the context of constitutional interpretation, including a pair of Eighth Amendment cases where the Supreme Court relied on international or foreign sources in order to ascertain whether evolving norms prohibited certain types of punishment. The concept can be given various interpretations.

1. A Global Constitution. Governments must obey a global constitution, one that sets the limits of power for all governments around the world. These limits are universal; perhaps they are embodied in human rights treaties. By applying to all governments, the global constitution protects all people, regardless of nationality. This does not necessarily mean that a government must treat noncitizens and citizens the same in all respects; just that noncitizens and citizens have certain identical basic rights. ${ }^{29}$

\footnotetext{
${ }^{24}$ Justice Kennedy furiously distinguishes away the contrary cases but never explicitly recognizes the cosmopolitan implications of his holding.

${ }^{25}$ See Ross v. McIntyre, 140 U.S. 453 (1891); Eisentrager, supra; Reid v. Covert, 354 U.S. 1 (1957); VerdugoUrquidez, 494 U.S. 259.

${ }^{26}$ Especially, Reid v. Covert, 354 U.S. at 6 (noting government "can only act in accordance with all the limitations imposed by the Constitution"). See also Rasul, 542 U.S. at 484 n. 15; and J. Andrew Kent, A Textual and Historical Case Against a Global Constitution, 95 Georgetown L.J. 463, 478 (2007); Paul B. Stephan, Constitutional Limits on the Struggle Against International Terrorism: Revising the Rights of Overseas Aliens, 19 Conn. L. Rev. 831 (1987).

${ }^{27}$ With the ambiguous exception of the Insular cases, on which see below.

${ }^{28}$ But unlikely if Parhat is any indication. See Parhat v. Gates, No. 06-1397 (D.C. Cir. 2008).

${ }^{29}$ I have not found an American scholar who has made this claim in quite so bald a form, as it would be inconsistent with Supreme Court jurisprudence as it currently exists. But this idea has currency among foreign scholars. See, e.g., Ernst-Ulrich Petersmann, Constitutional Functions and Constitutional Problems of International
} 
2. A Cosmopolitan-American Constitution. The U.S. Constitution itself embodies certain global constitutional commitments, including the commitment to respect the rights of all people, regardless of nationality. Thus, any rights in the U.S. Constitution that protect Americans also protect noncitizens. Observed limits on rights granted to nonresident aliens are the result of logistical constraints, not lower constitutional status of noncitizens. ${ }^{30}$

3. Residual Constitutionalism. The U.S. Constitution does not apply in foreign countries that have governments; but it does apply in places, like Guantanamo Bay, where there is no government. Nations states and sovereigns get priority otherwise. ${ }^{31}$

These definitions differ as to the strength of the rights granted to nonresident aliens under the U.S. Constitution, but they agree that they do have at least some rights, and that is the minimalist sense in which I will use the term judicial cosmopolitanism. ${ }^{32}$

B. What Is the Justification for Judicial Cosmopolitanism?

What should we think of judicial cosmopolitanism? The literature is overwhelmingly favorable. However, the relevant historical and textual sources are sporadic and ambiguous, and authors end up relying on a claim that human rights are universal and judges should ensure that the U.S. government does not violate any human rights. ${ }^{33}$ I will address this theory shortly. But some theoretical throatclearing must come first.

One cannot address judicial cosmopolitanism without a theory of the judicial role in the constitution system. There are as many such theories as there are constitutional theorists, and to keep the argument simple, I will focus on the simplest and most plausible of these theories-the democratic failure theory associated with John Hart Ely and footnote 4 of Carolene Products. ${ }^{34}$ According to this theory, our majoritarian political system can survive and prosper only if courts guard against

Economic Law (1991). American scholars usually refer to the idea of "dialogue" between the Supreme Court and foreign courts, but it is not clear what this term means. See, e.g., Gerald L. Neuman, The Uses of International Law in Constitutional Interpretation, 98 Am. J. Int'I L. 82, 87 (2004). There is a less ambitious epistemic interpretation of Roper, which does not rely on any version of judicial cosmopolitanism: aliens are a source of information only. See Eric A. Posner \& Cass R. Sunstein, The Law of Other States, 59 Stan. L. Rev. 1309 (2007).

${ }^{30}$ Cf. Verdugo-Urquidez, 494 U.S. at 275 (Kennedy, J., concurring). This is what Neuman calls "mutualism": see Gerald L. Neuman, Strangers to the Constitution: Immigrants, Borders, and Fundamental Law (Princeton University Press, 1996).

${ }^{31}$ Cf. Munaf v. Geren, No. 06-1666, slip op. (U.S. 2008), where the Supreme Court refused to prevent the U.S. military from turning over American criminal suspects in Iraq to the Iraqi government, because the Iraqi government was sovereign.

${ }_{32}$ As does, for example, Kent. See J. Andrew Kent, A Textual and Historical Case Against a Global Constitution, 95 Georgetown L.J. 463, 470 (2007).

${ }^{33}$ See, e.g., Neuman, supra; David Cole, Are Foreign Nationals Entitled to the Same Constitutional Rights as Citizens?, 25 T. Jefferson L. Rev. 367 (2003); Kal Raustiala, The Geography of Justice, 73 Fordham L. Rev. 2501). For dissent, see Paul B. Stephan, Constitutional Limits on the Struggle Against International Terrorism: Revising the Rights of Overseas Aliens, 19 Conn. L. Rev. 831 (1987); Kent, supra.

${ }^{34}$ John Hart Ely, Democracy and Distrust: A Theory of Judicial Review (1980); United States v. Carolene Products Co., 304 U.S. 144, 153 n.4 (1938). 
"democratic failures." This idea can be cashed out in two ways. First, a democratic failure exists when a particular group is systematically excluded from the political decisionmaking process, as AfricanAmericans were during the Jim Crow era. Second, a democratic failure exists when the political process does not generate policies that satisfy a relatively uncontroversial welfarist principle-for example, a principle that bars transferring resources from out-of-power groups to in-power groups while reducing, or not increasing, total social welfare. The overall concern is that groups within democracy obtain control of the government through democratic means but then use the power at their disposal to weaken democratic institutions so as to undermine political competition.

The immediate problem that the usual analysis skirts is the scope of the demos. ${ }^{35}$ In the first case, which emphasizes exclusion of groups from political decisionmaking, we need to know which groups count as a part of the demos. If Congress passes a tariff that advances the political interests of constituents, while injuring people who live in Haiti, one would not normally call this tariff the result of a democratic failure. Quite the contrary, Congress advances the interests of American public. However harmful the law for Haitians, they can't complain that they have been unfairly excluded from the demos because they are not American citizens.

Some scholars have rejected this argument. Some have argued, at least with respect to resident aliens, that they should have a vote because they are regulated by the government. ${ }^{36}$ The principle seems to be that anyone who is directly affected by government policy should have a say in it. The logic of this argument would seem to imply that the Haitians should have a vote in American elections, or at least a vote in decisions that affect Haiti. Few people take this view, and so I will put it aside for reasons of space. ${ }^{37}$

Another view is that courts should grant constitutional protections to noncitizens just because they cannot vote, and therefore they belong to a minority that can be exploited by the vote-holding majority. This view has been prominent among advocates for resident aliens, and the Supreme Court has indeed given them many rights. ${ }^{38}$ But this view, like the earlier one, is question-begging. If resident aliens should be considered part of the political community, then they should have the right to vote as well as other constitutional rights. If not, and therefore they are not entitled to the right to vote, it's not clear why they should enjoy the other rights protections. Put differently, if we are concerned that citizens will abuse resident aliens, then the democratic failure argument is just that resident aliens should be given citizenship.

Another theory tries to evade these problems by asserting that everyone in the world has human rights, and that it is the obligation of courts to protect the human rights of aliens against policies

\footnotetext{
${ }^{35}$ For a discussion of this problem in the context of the treatment of resident aliens, see Eric A. Posner \& Adrian Vermeule, Terror in the Balance: Security, Liberty, and the Courts 275 (2007).

${ }^{36}$ Joseph H. Carens, Culture, Citizenship and Community: A Contextual Exploration of Justice as Evenhandedness, Oxford University Press Inc, New York (2000).

${ }^{37}$ See, e.g., Robert E. Goodin, Enfranchising All Affected Interests, and Its Alternatives, 35 Philosophy \& Pub. Aff. 40 (2007). Various philosophers have argued for world government or a version of it, which could in theory solve this problem. For now, and the foreseeable future, however, world government is not in the cards.

${ }^{38}$ See Ely, supra.
} 
of the U.S. government that harm them. Even if so, the question, which I will address in Part IV, is whether there is reason in constitutional theory for courts to force the political branches to respect human rights. The human rights treaties have been negotiated and ratified by the political branches, which have declared that the courts may not enforce them except insofar as they are incorporated in domestic law. Under the human rights treaties, states have an obligation to refrain from arbitrary detentions, but they don't have an obligation to give habeas rights to victims of arbitrary detentions. If states seek to comply with their treaty obligations by authorizing courts to review detentions of noncitizens captured overseas, they are free to do so. A constitutional theory would need to show that American judges should compel the U.S. government to go beyond its treaty commitments, perhaps because human rights exist in natural law and courts have a constitutional obligation to compel the government to obey natural law.

Let us turn to the welfarist approach. Initially, we must distinguish between two types of welfarism: national and global. For national welfarism, the social welfare function includes only citizens of the nation state. For global welfarism, the social welfare function includes everyone in the world.

National welfarism provides the cleanest explanation for the traditional view that constitutional rights stop at the shoreline. Americans "count" in the social welfare function; non-Americans do not count; therefore, courts have no reason to extend protections to non-Americans. Eisentrager reflects this approach. Recall Justice Jackson's brief comment that "the right of judicial refuge from military action, which it is proposed to bestow on the enemy, can purchase no equivalent for benefit of our citizen soldiers." ${ }^{39} \mathrm{He}$ is saying that there could be a policy reason to extend habeas corpus to enemy soldiers, namely, that if we do so, then enemy courts might be opened to American soldiers. This type of reciprocal logic is the traditional basis for the laws of war, where we treat enemy POWs humanely so that the enemy treats American POWs humanely. The humane treatment of enemy soldiers is derived entirely from gains to Americans; the enemy soldiers themselves don't count in the social welfare function.

National welfarism is philosophically disreputable but has the offsetting advantage of empirical accuracy. There is little doubt that the American political system as a whole favors Americans, greatly at the expense of people who live in other countries. ${ }^{40}$ But if national welfarism is the premise upon which the democratic failure theory is set up, then it follows that courts have no business granting rights to noncitizens. The political branches, acting for the benefit of the citizenry, can certainly make deals with foreign governments, including that of making habeas available to foreign citizens in return for similar treatment of Americans by foreign governments, but courts have no reason to compel such an outcome on their own, except in the extremely unlikely case that the failure to do so can be traced to domestic laws that reduce the welfare of Americans.

That leaves global welfarism. A global welfarist argument for extraterritorial constitutionalism is that the political branches have no, or very weak, incentives to take account of the well-being of

\footnotetext{
39 Eisentrager, 339 U.S. at 779.

${ }^{40}$ See Wojciech Kopczuk, Joel Slemrod, and Shlomo Yitzhaki, The Limitations of Decentralized World Redistribution: An Optimal Taxation Approach, 49 European Econ. Rev. 1051 (2005).
} 
noncitizens because noncitizens don't vote. Democratic failure arises because the demos consists of the global population but only a small fraction of it-American citizens-can vote for American government officials who affect the greater demos. Americans have strong incentives to compel their leaders to adopt policies that effect transfers from the rest of the world to the United States. Courts can block these transfers, or at least the worst of them-including detentions of people on the basis of weak evidence of dangerousness.

One might object that, if this is really a problem, judges should compel the political branches to grant the vote to foreigners living in foreign countries. The sufficient response is that this would be impractical, whereas judges do seem to have the power to compel the political branches to respect at least some minimal rights, such as the right not to be arbitrarily detained. So why shouldn't they do this?

One conjectures that Justice Kennedy and the four justices who signed his opinion would, if forced to answer this question, agree that the U.S. government should respect the rights of nonresident aliens, subject to logistical and other practical constraints. ${ }^{41}$ Whether or not that they think that aliens "count" in the social welfare function to the same extent as Americans do, they surely think that they do "count" at least a little, and therefore the "demos" for purposes of the democratic failure theory, extends across the world. Or perhaps they do not think in welfarist terms, but just think that nonresident aliens have certain basic rights. Nonresident aliens are not treated as the classic discrete and insular minority, regulation of whom requires strict scrutiny. They are not citizens, after all; perhaps, one should call them second-class citizens. Their interests must be given some weight; the government, influenced entirely by voters, has no incentive to give those interests any weight; and therefore, judicial intervention is justified.

\section{The Connection Between Boumediene and the Foreign Law Debate}

From this perspective, we can reconsider the style of cosmopolitanism seen in cases like Roper v. Simmons, where, in an opinion written by Justice Kennedy, the Supreme Court cited foreign and international law sources in the course of holding that the eighth amendment bars the death penalty for crimes committed by juveniles. ${ }^{42}$ This practice can be defended on purely epistemic grounds-the laws of other states might provide relevant information for judicial decisionmaking where local law authorizes judges to use such information. This justification for using foreign law sources is not cosmopolitan: one uses information from abroad but not in order to protect the interests of noncitizens or show respect for them. Nor does this justification has much to do with Boumediene. ${ }^{43}$

The more ambitious and cosmopolitan justification for use of foreign law goes farther. Consider, for example, this statement by former Justice Sandra Day O'Connor:

Doing so [citing foreign sources] may not only enrich our own country's decisions; it will create that all important good impression. When U. S. courts are seen to be cognizant of

\footnotetext{
${ }^{41}$ See also Verdugo-Urquidez, 494 U.S. at 275 (Kennedy, J., concurring).

${ }^{42}$ Roper, supra. See also Atkins v. Virginia, 536 U.S. 304 (2002); Lawrence, 539 U.S. 558.

${ }^{43}$ See Posner \& Sunstein, supra.
} 
other judicial systems, our ability to act as a rule-of-law model for other nations will be enhanced. ${ }^{44}$

The statement, taken literally, suggests a vision of U.S. courts interpreting the American constitution in a manner that, at least at the margin, defers to foreign sensibilities, in return for which foreign courts follow American jurisprudence-again, at least at the margin. On the American side, the Court would cut back on constitutional norms that many Americans approve of-say, freedom of speech or the permissibility of the death penalty. On the foreign side, American constitutional norms would increasingly influence their national law-say, stronger abortion rights or a right to bear arms.

What is the justification for this approach? American judges confer benefits on Americansperhaps, strengthening their rights in foreign countries, or perhaps advancing their presumed political/constitutional interests in those lands-in return for which American judges accept constraints on American constitutional norms at home. In a stronger form, perhaps it is not even necessary for American norms to travel abroad. In the weaker form, reciprocity occurs, albeit of an odd sort. From our perspective (not theirs), foreigners benefit from the extension of American constitutional norms to their states, while from their perspective (not ours) we benefit from the extension of their norms to our state. We want them to accept our norms; they want us to accept theirs. All these notions are outside American traditional jurisprudence. ${ }^{45}$ We are used to encouraging other countries to adopt American constitutional norms, but we have never accepted the idea that we should adopt theirs-and even less, the idea that this adoption of foreign constitutional norms should take place at the hands of our judges.

Now one could think of the reciprocal version of this idea-we give up some of our constitutional norms and you give up some of ours - as not really cosmopolitan because, in theory, Americans gain from a kind of constitutional-level bargain. But in practice the willingness to even consider such a bargain in the first place, against the background of American exceptionalism, suggests an openness to alien norms, and a concern about showing respect to noncitizens, that is the essence of cosmopolitanism. The nonreciprocal version of this idea-we give up some of our constitutional norms just because they diverge from yours-is just a more extreme version of this openness.

So Roper and cases like it take seriously the interests of nonresident aliens-seriously enough to permit their moral interests to influence American constitutional law-not just the common law, which of course can be easily changed. Boumediene does the same. Although Roper cited foreign law in order to protect Americans, and Boumediene cited American law in order to protect foreigners, the thrust of both cases was that of advancing the interests of noncitizens, their moral interest in limiting the death

\footnotetext{
${ }^{44}$ Sandra Day O'Connor, Assoc. Justice, U.S. Supreme Court, Remarks at the Southern Center for International Studies (Oct. 28, 2003) (transcript available at www.southerncenter.org/OConnor_transcript.pdf).

${ }^{45}$ Mark Tushnet refers to a tradition of American "engagement" but cites political documents, not judicial opinions, and seems to acknowledge the novelty of the reciprocity idea. Mark Tushnet, When Is Knowing Less Better Than Knowing More? Unpacking the Controversy over Supreme Court Reference to Non-U.S. Law, 90 Minn. L. Rev. 1275 (2006) (“Perhaps merely explaining ourselves might have been enough in 1776 or 1862 . But today, others will not listen unless we display some reciprocity.").
} 
penalty and arbitrary detention, their individual interests in freedom, at the expense of traditional American constitutional understandings.

There are two earlier sets of cases that are relevant but that did not go so far as the modern cases. First, there are the Insular cases, but in those cases, the affected people, while not Americans, were not aliens either. They were subject to no foreign government and in those days few people would have claimed that the international community had any interest in their well-being. They were colonial subjects, and although the Court, by granting them some constitutional rights, was more cosmopolitan than the political branches responsible for their conquest and subjugation, this was a minimal type of cosmopolitanism indeed.

Second, there are cases that grant constitutional rights, albeit of a limited sort, to noncitizens on American soil. I mentioned earlier that noncitizens on American soil enjoy habeas rights as well as other constitutional rights, a point that Justice Jackson noted in Eisentrager. This has led to the following chain of reasoning. If noncitizens on sovereign American territory have constitutional rights, then it can't be the case that the Constitution draws a line between noncitizens and American citizens, and gives rights only to the latter. If that is the case, then the Constitution is not "nationalistic"; it is already cosmopolitan, and has been recognized as such for many years. It follows that the only possible explanation for traditional judicial reluctance to extend habeas to noncitizens abroad is that of logistics, and it therefore would be wrong to assume that Eisentrager drew a sharp line between noncitizens and American citizens. And so where logistics do not pose an insurmountable problem, habeas and other constitutional rights should be granted to noncitizens. On this view, Boumediene did no more than follow Eisentrager, a version of the narrow interpretation discussed in Part I.A.

However, Americans abroad enjoy greater rights than noncitizens abroad do, and Americans at home enjoy greater rights than noncitizens at home do (including, in particular, the right to vote, but also many constitutional protections). So, as a matter of tradition, noncitizens "count" less than Americans do; it's just that the noncitizen's disadvantage is greater when he or she is abroad than when he or she is on American territory. Boumediene certainly does not erase this disadvantage, but it does erode it, or portend such an erosion, assuming that in subsequent years the Supreme Court does not reverse course and refuse to grant substantive constitutional rights to nonresident aliens.

Still, the question can be asked, What is the constitutional reason for granting resident noncitizens any rights at all? The best answer probably would start from the premise that there is no reason to think that the all people can be divided into two categories, citizen and non-citizen. There is a hazy third category, the quasi-citizen, that consists of people who have partly but not fully committed themselves to a polity. In the United States, these people are lawfully admitted noncitizens and, in particular, lawful permanent residents. Courts have granted these people (some) rights because they have made their way (partly) into the demos, and thus are (partly) vulnerable to democratic failure. This 
is not cosmopolitan or only ambiguously cosmopolitan-much like an open immigration law itselfbecause the status of the long-term resident is not clearly alien. ${ }^{46}$

\section{A Brief Critique}

The broad reading of Boumediene, which suggests a sneaking cosmopolitanism in Supreme Court jurisprudence, raises the question whether Justice Kennedy's cosmopolitan approach to habeas is wise. One cannot answer this question without taking a position on whether the demos is national or global; I will start with the first assumption.

The national demos consists of American citizens at home and abroad, plus various quasicitizens such as lawful permanent residents. These people have values and interests that no doubt concern people living abroad. Some of these interests are intrinsic, others are instrumental. Some Americans care about the well-being of the poor in other countries, and this concern appears as government foreign aid and related projects, which, though no doubt reflecting other motivations as well, at least partly reflect altruistic or cosmopolitan commitments. In addition, Americans benefit when their government makes deal with foreign governments, including trade deals, for example; here, noncitizens benefit but only as a means toward benefiting Americans.

None of these values and interests implies a constitutional role for the courts. As noted in Part III.B., the U.S. government has normal electoral incentives to respect altruistic interests of citizens, and to make deals with foreign government in order to advance Americans' interests. Sometimes such deals are possible, sometimes they are not. As Justice Jackson recognized, the United States gains by extending habeas protections to enemy soldiers only if foreign states grant similar protections to Americans. There was no reason in Justice Jackson's time to think that they would, and there is no reason today. Reciprocal rights are extended through negotiations between governments. Unilateral action by courts to grant unreciprocated benefits to noncitizens simply weakens the bargaining power of their own government.

Justice O'Connor hinted that the exchange of rights occurs at the constitutional level and is handled by judges rather than politicians. But she does not explain why judges should have this role, or even if the purported exchanges go through as intended. What will Americans obtain as a result of the Court's grant of habeas protections to noncitizens in Guantanamo Bay? What exactly did they receive in return for giving up the juvenile death penalty? Europeans seem no more inclined to adopt American religious freedoms than in the past, and would we really gain if they did?

These questions are not meant to deny the benefits that result when governments reciprocally advance the interests of noncitizens. The question is one of judicial competence and constitutional theory. In the framework of the democratic failure theory with a national demos, we would need to suppose that American judges restrain the American government because otherwise the American

\footnotetext{
${ }^{46}$ On the correlation between level of constitutional protection and extent to which a person has entered the demos, see, e.g., David A. Martin, Graduated Constitutional Protections for Aliens: The Real Meaning of Zadvydas v. Davis, 2001 Sup. Ct. Rev. 47.
} 
government would shun opportunities to advance the rights and interests of a discrete and insular minority of Americans by making deals with foreign governments. Because of democratic failure the U.S. government neglects to protect Americans abroad by offering fair process to detainees, and because of democratic failure the U.S. government (or state governments) neglects to influence European constitutional norms by rejecting the juvenile death penalty. Neither of these propositions has any plausibility. Because these benefits-protection of Americans abroad, influence on Europe-would go to Americans generally, rather than to a particular minority, these failures are not democratic failures. ${ }^{47}$ If Guantanamo Bay has been a failure, if it has caused more harm to the United States than good, this is just a policy failure for which the Bush administration is responsible. Governments make policy mistakes all the time; it is not the role of courts to correct them.

And even if we were to accept the idea that courts should make constitutional deals directly with foreign constitutional courts, with our courts restraining our government for the sake of foreign interests so that foreign courts restrain their government for the sake of American interests, there is no evidence that Americans are getting anything out of these bargains; indeed, most foreign courts do not have the power to deliver their governments. This leaves the suspicion that there are no exchanges, that the influence is really going only one way, so that noncitizens are being invited into our demos without us being invited into theirs. The interests of noncitizens are treated as constitutional ends; protection of those interests is not merely an instrument for securing the constitutional interests of Americans overseas. If the demos is national, there is no justification for such an outcome.

Let us turn to a more promising basis for judicial cosmopolitanism: that the demos is actually global, not national. Hence democratic failure occurs because the U.S. government has no electoral incentive to take account of the interests of people living abroad. Courts should therefore strike down laws and block other government actions that (for example) unreasonably burden noncitizens abroad. This is a perfectly coherent view, albeit subject to a series of standard pragmatic objections. Courts that take this position run the risk that they hamstring their own government's ability to advance the interests of Americans by weakening its bargaining power, but they also would be concerned that when the government advances the interests of Americans, it harms the interests of others. Courts might also worry that they do not have the institutional competence to understand the interests of people living in other countries, their values and priorities, the reliability of their governments' claims about them, and so forth. But these are pragmatic issues, and conceivably a cosmopolitan justice would be justified in ignoring them-especially if he or she thinks that the American government's regard for nonresident aliens falls well short of what is morally required.

This view would take the Court far beyond anything it has done before. Consider a new tariff bill that harms some exporters in Haiti but benefits some export-competers in Haiti, while benefiting some workers in the Dominican Republic because of trade diversion-with both governments offering to raise or lower cooperation with respect to various diplomatic initiatives in the Caribbean if the U.S. Congress does (or does not) pass the bill. Should the Court review this law in order to ensure that the interests of

${ }^{47}$ Cf. Roger P. Alford, In Search of a Theory for Comparative Constitutionalism, 52 UCLA L. Rev. 639 (2005), who
similarly doubts that democratic failure theory justifies reliance on foreign law for constitutional interpretation. 
noncitizens are appropriately taken into account? No one seems to think so. Yet the hardship imposed on Haitians thrown out of work could be just as significant as a detention, and would be constitutionally suspect under the democratic failure theory assuming a global demos. If a law strips habeas protections of noncitizens, so that Americans and some noncitizens benefit from the increased security while other noncitizens, including the detainees, are harmed, the question is no easier. And these questions are not very different from the question whether Europeans would, in general, benefit or be harmed if the United States eliminated the death penalty, and to what extent. Some noncitizens would be, others not; again all questions that are beyond judicial competence under any reasonable conception of it.

Whatever its merits, one doubts that such an approach is sustainable. Aside from the sheer complexity of evaluating American laws that affect foreigners abroad, it gives courts the difficult task of resisting the political interests of government, whichever party controls it. Many scholars believe that the Supreme Court maintains its power by staying close to the political center. Protecting noncitizens, by contrast, will put the Supreme Court outside the mainstream, regardless of which party is in power, unless the cases have little practical importance. Boumediene itself has received praise from Democrats, but it seems doubtful that more aggressive efforts by courts to protect the interests of nonresident aliens would be welcome, especially if Democrats take control of the presidency. ${ }^{48}$ If the Court must stay close to the political center, then even approaches to the Constitution that incorporate moral principles must rely on a morality rooted in the sensibilities of citizens, who are not themselves notably cosmopolitan.

Conclusion

If the Boumediene case is remembered, it will be remembered not as a separation-of-powers case, but as one more step in the march of judicial cosmopolitanism-the emerging view that the interests of nonresident aliens deserve constitutional protection secured by judicial review. The constitutional basis for this view remains to be worked out. Although it may be good policy for the American government to respect, or at least take account of, the interests and values of foreigners, it is not clear why American judges should compel the government to do so by giving overseas aliens the right to bring actions against it in American courts, or by incorporating foreign norms into American constitutional law.

Readers with comments may address them to:

Professor Eric A. Posner

University of Chicago Law School

1111 East 60th Street

Chicago, IL 60637

eposner@uchicago.edu ${ }^{48}$ For example, the Clinton administration's treatment of Haitian refugees, who were also detained in Guantanamo
Bay. 


\section{The University of Chicago Law School Public Law and Legal Theory Working Paper Series}

For a listing of papers 1-99 please go to http://www.law.uchicago.edu/academics/publiclaw/1-99.html

100. Mary Anne Case, Pets or Meat (August 2005)

101. Adam Samaha, Executive Exposure: Government Secrets, Constitutional Law, and Platforms for Judicial Intervention (August 2005, revised November 2005)

102. Jason J. Czarnezki and William K. Ford, The Phantom Philosophy? An Empirical Investigation of Legal Interpretation (August 2005)

103. Adrian Vermeule, Absolute Voting Rules (August 2005)

104. Eric A. Posner and Adrian Vermeule, Emergencies and Democratic Failure (August 2005)

105. Adrian Vermeule, Reparations as Rough Justice (September 2005)

106. Arthur J. Jacobson and John P. McCormick, The Business of Business Is Democracy (September 2005)

107. Tracey Meares and Kelsi Brown Corkran, When 2 or 3 Come Together (October 2005)

108. Adrian Vermeule, Political Constraints on Supreme Court Reform (October 2005)

109. Lior Jacob Strahilevitz, Information Asymmetries and the Rights to Exclude (November 2005)

110. Cass R. Sunstein, Fast, Frugal and (Sometimes) Wrong (November 2005)

111. Cass R. Sunstein, Justice Breyer's Democratic Pragmatism (November 2005)

112. Adam M. Samaha, Endorsement Retires: From Religious Symbols to Anti-Sorting Principles (November 2005)

113. Adam M. Samaha, Undue Process: Congressional Referral and Judicial Resistance in the Schiavo Controversy (November 2005)

114. Bernard E. Harcourt, Should We Aggregate Mental Hospitalization and Prison Population Rates in Empirical Research on the Relationship between Incarceration and Crime, Unemployment, Poverty, and Other Social Indicators? On the Continuity of Spatial Exclusion and Confinement in Twentieth Century United States (January 2006)

115. Elizabeth Garrett and Adrian Vermeule, Transparency in the Budget Process (January 2006)

116. Cass R. Sunstein, Burkean Minimalism (January 2006)

117. Stephanos Bibas, Transparency and Participation in Criminal Procedure (February 2006)

118. Douglas G. Lichtman, Captive Audiences and the First Amendment (February 2006)

119. Eric A. Posner and Cass R. Sunstein, The Law of Other States (March 2006)

120. Jeff Leslie and Cass R. Sunstein, Animal Rights without Controversy (March 2006)

121. Adrian Vermeule, The Delegation Lottery (March 2006)

122. Adrian Vermeule, Self-Defeating Proposals: Ackerman on Emergency Powers (March 2006)

123. Bernard E. Harcourt, Muslim Profiles Post 9/11: Is Racial Profiling an Effective Counterterrorist Measure and Does It Violate the Right to Be Free from Discrimination? (March 2006)

124. Christine Jolls and Cass R. Sunstein, The Law of Implicit Bias (April 2006)

125. Lior Strahilevitz, “How’s My Driving?” for Everyone (and Everything?) (April 2006)

126. Jack Goldsmith and Eric A. Posner, The New International Law Scholarship (May 2006)

127. Eric A. Posner and John Yoo, International Law and the Rise of China (May 2006)

128. Eric A. Posner and Cass R. Sunstein, Chevronizing Foreign Relations Law (May 2006)

129. Jacob E. Gersen and Adrian Vermeule, Chevron as a Voting Rule (June 2006)

130. Jacob E. Gersen, Temporary Legislation (June 2006)

131. Adam B. Cox, Designing Redistricting Institutions (June 2006)

132. Adam B. Cox, The Temporal Dimension of Voting Rights (July 2006)

133. Curtis A. Bradley and Eric A. Posner, Presidential Signing Statements and Executive Power (July 2006) 
134. Cass R. Sunstein, Clear Statement Principles and National Security: Hamdan and Beyond (July 2006)

135. Cass R. Sunstein, Of Snakes and Butterflies: A Reply (August 2006)

136. Cass R. Sunstein, Montreal versus Kyoto: A Tale of Two Protocols (September 2006)

137. Douglas Lichtman, Irreparable Benefits (September 2006)

138. Adam M. Samaha, Undue Process (September 2006)

139. Eric A. Posner and Adrian Vermeule, The Credible Executive (September 2006)

140. Adam B. Cox and Eric A. Posner, The Second-Order Structure of Immigration Law (November 2006)

141. Eric A. Posner, The International Protection of Cultural Property: Some Skeptical Observations (November 2006)

142. Bernard E. Harcourt and Jens Ludwig, Reefer Madness: Broken Windows Policing and Misdemeanor Marijuana Arrests in New York City, 1989-2000 (December 2006)

143. Bernard E. Harcourt, Embracing Chance: Post-Modern Meditations on Punishment (December 2006)

144. Cass R. Sunstein, Second-Order Perfectionism (December 2006)

145. Wayne Hsiung and Cass R. Sunstein, Climate Change and Animals (January 2007)

146. Cass R. Sunstein, Deliberating Groups versus Prediction Markets (or Hayek’s Challenge to Habermas) (January 2007)

147. Cass R. Sunstein, Incompletely Theorized Agreements in Constitutional Law (January 2007)

148. Eric A. Posner, Climate Change and Human Rights Litigation: A Critical Appraisal (January 2007)

149. Cass R. Sunstein, Cost-Benefit Analysis without Analyzing Costs or Benefits: Reasonable Accommodation, Balancing, and Stigmatic Harms (January 2007)

150. Cass R. Sunstein, Willingness to Pay versus Welfare (January 2007)

151. Cass R. Sunstein, If People Would Be Outraged by Their Rulings, Should Judges Care? (February 2007)

152. Bernard E. Harcourt, Judge Richard Posner on Civil Liberties: Pragmatic Authoritarian Libertarian (March 2007)

153. Eugene Kontorovich, What Standing Is Good For (March 2007)

154. Eugene Kontorovich, Inefficient Customs in International Law (March 2007)

155. Bernard E. Harcourt, From the Asylum to the Prison: Rethinking the Incarceration Revolution. Part II: State Level Analysis (March 2007)

156. Bernard E. Harcourt, An Answer to the Question: “What Is Poststructuralism?” (March 2007)

157. Cass R. Sunstein, Backlash’s Travels (March 2007)

158. Cass R. Sunstein, Due Process Traditionalism (March 2007)

159. Adam B. Cox and Thomas J. Miles, Judging the Voting Rights Act (March 2007)

160. Jonathan F. Mitchell, Apprendi’s Domain (April 2007)

161. Jacob E. Gersen, Overlapping and Underlapping Jurisdiction in Administrative Law (April 2007)

162. Eric A. Posner and Cass R. Sunstein, On Learning from Others (April 2007)

163. Eric A. Posner and Adrian Vermeule, Originalism and Emergencies: A Reply to Lawson (April 2007)

164. Cass R. Sunstein, Illusory Losses (April 2007)

165. Josh Bowers, Punishing the Innocent (April 2007)

166. Adam M. Samaha, What Good Is the Social Model of Disability? (May 2007)

167. Cass R. Sunstein, On the Tension between Sex Equality and Religious Freedom (June 2007)

168. Jacob E. Gersen, Legislative Rules Revisited (June 2007)

169. Josh Bowers, Grassroots Plea Bargaining (June 2007)

170. Julie Roin, Can the Income Tax Be Saved? The Promise and Pitfalls of Unitary Formulary Apportionment (April 2007)

171. Daniel Kahneman and Cass R. Sunstein, Indignation: Psychology, Politics, Law (July 2007)

172. Jacob E. Gersen and Eric A. Posner, Timing Rules and Legal Institutions (July 2007) 
173. Eric A. Posner and Adrian Vermeule, Constitutional Showdowns (July 2007)

174. Lior Jacob Strahilevitz, Privacy versus Antidiscrimination (July 2007)

175. Bernard E. Harcourt, A Reader's Companion to Against Prediction: A Reply to Ariela Gross, Yoram Margalioth and Yoav Sapir on Economic Modeling, Selective Incapacitation, Governmentality, and Race (July 2007)

176. Cass R. Sunstein, The Complex Climate Change Incentives of China and the United States (August 2007)

177. Eric A. Posner an Cass R. Sunstein, Climate Change Justice (August 2007)

178. Jonathan Remy Nash, Standing and the Precautionary Principle (August 2007)

179. William Meadow and Cass R. Sunstein, Causation in Tort: General Populations vs. Individual Cases (August 2007)

180. Josh Bowers, Contraindicated Drug Courts (August 2007)

181. Timur Kuran and Cass R. Sunstein, Availability Cascades and Risk Regulation (September 2007)

182. Shyamkrishna Balganesh, "Demystifying the Right to Exclude: Of Property, Inviolability, and Automatic Injunctions” (September 2007)

183. Robin Effron, Event Jurisdiction and Protective Coordination: Lessons from September 11th Litigation (October 2007)

184. Richard H. McAdams and Janice Nadler, Coordinating in the Shadow of hte Law: Two Contextualized Tests (October 2007)

185. Richard H. McAdams, Reforming Entrapment Doctrine in United States v. Hollingsworth (October 2007)

186. M. Todd Henderson, From Seriatim to Consensus and Back Again: A Theory of Dissent (October 2007)

187. Jonathan R. Nash and Rafael I. Pardo, An Empirical Investigation into Appellate Structure and the Perceived Quality of Appellate Review (October 2007)

188. Thomas J. Miles and Cass R. Sunstein, The Real World of Arbitrariness Review (November 2007)

189. Richard H. McAdams, The Economic Costs of Inequality (November 2007)

190. Lior Jacob Strahilevitz, Reputation Nation: Law in an Era of Ubiquitous Personal Information (November 2007)

191. Thomas J. Miles and Cass R. Sunstein, The New Legal Realism (December 2007)

192. Jonathan Nash, Economic Efficiency versus Public Choice: The Case of Property Rights in Road Traffic Management (December 2007)

193. Edward L. Glaeser and Cass R. Sunstein, Extremism and Social Learning (December 2007)

194. Adam M. Samaha, Dead Hand Arguments and Constitutional Interpretation (January 2008)

195. Eric A. Posner, Does Political Bias in the Judiciary Matter?: Implications of Judicial Bias Studies for Legal and Constitutional Reform (January 2008)

196. Jacob E. Gersen and Anne Joseph O’Connell, Deadlines in Administrative Law (January 2008)

197. Alison L. LaCroix, The New Wheel in the Federal Machine: From Sovereignty to Jurisdiction in the Early Republic (January 2008)

198. Cass R. Sunstein, Adolescent Risk-Taking and Social Meaning: A Commentary (January 2008)

199. Cass R. Sunstein and Adrian Vermeule, Conspiracy Theories (January 2008)

200. Susan Bandes, The Heart Has Its Reasons: Examining the Strange Persistence of the American Death Penalty (January 2008)

201. Susan Bandes, After Innocence: Framing Wrongful Convictions (January 2008)

202. Ariel Porat, Expanding Restitution: Liability for Unrequested Benefits (January 2008)

203. Adam B. Cox, Deference, Delegation and Immigration Law (February 2008)

204. Ariel Porat and Alon Harel, Aggregating Probabilities across Offences in Criminal Law (March 2008)

205. Jonathan S. Masur, Process as Purpose: Administrative Procedures, Costly Screens, and Examination at the Patent Office (March 2008, revised July 2008) 
206. Eric A. Posner and Cass R. Sunstein, Should Green house Gas Permits Be Allocated on a Per Capita Basis? (March 2008)

207. Eric A. Posner, Human Welfare, Not Human Rights (March 2008)

208. Susan Bandes, Victims, “Closure,” and the Sociology of Emotion (March 2008)

209. Cass R. Sunstein, Is OSHA Unconstitutional? (March 2008)

210. Shyamkrishna Balganesh, Foreseeability and Copyright Incentives

211. Lee Fennell, Slices and Lumps (March 2008)

212. M. Todd Henderson, Citing Fiction (March 2008)

213. Jacob E. Gersen and Eric A. Posner, Soft Law (March 2008)

214. Christopher R. Berry and Jacob E. Gersen, The Unbundled Executive (March 2008)

215. Cass R. Sunstein and Reid Hastie, Four Failures of Deliberating Groups (April 2008)

216. Adam M. Samaha, Judicial Transparency in an Age of Prediction (April 2008)

217. Stephen J. Choi, Mitu Gulati, \& Eric A. Posner, Which States Have the Best (and Worst) High Courts? (May 2008)

218. Cass R. Sunstein, Two Conceptions of Irreversible Environmental Harm (May 2008)

219. Jonathan R. Nash, The Uneasy Case for Transjurisdictional Adjudication (June 2008)

220. Adam B. Cox and Thomas J. Miles, Documenting Discrimination? (June 2008)

221. Susan Bandes, Emotions, Values and the Construction of Risk (June 2008)

222. Jonathan R. Nash, Taxes and the Success of Non-Tax Market-Based Environmental Regulatory Regimes (July 2008)

223. Thomas J. Miles and Cass R. Sunstein, Depoliticizing Administrative Law (June 2008)

224. Eric A Posner, Erga Omnes Norms, Institutionalization, and Constitutionalism in International Law (July 2008)

225. Thomas J. Miles and Eric A. Posner, Which States Enter into Treaties, and Why? (July 2008)

226. Cass R. Sunstein, Trimming (August 2008)

227. Jonathan R. Nash, The Majority That Wasn't: Stare Decisis, Majority Rule, and the Mischief of Quorum Requirements (August 2008)

228. Eric A. Posner, Boumediene and the Uncertain March of Judicial Cospopolitanism (August 2008) 